Stanislav Ogorodov ${ }^{1}{ }^{*}$, Vasiliy Arkhipov ${ }^{2,1}$, Osip Kokin ${ }^{1}$, Aleksey Marchenko ${ }^{3,2}$, Paul Overduin ${ }^{4}$, Donald Forbes ${ }^{5}$

${ }^{1}$ Faculty of Geography, Lomonosov Moscow State University; Leninskiye Gory;

119991 Moscow, Russia; Tel: 7495 939-22-38; Fax: 7 (495) 932-88-36

* Corresponding author: e-mail: ogorodov@aha.ru

2 Zubov State Oceanographic Institute, Kropotkinskiy pereulok, 6, 119034, Moscow,

Russia; e-mail: vvarkhipov@mail.ru

${ }^{3}$ The University Centre in Svalbard, Pb. 1569171 Longyearbyen, Norway;

e-mail: aleksey.marchenko@unis.no

${ }^{4}$ Alfred Wegener Institute Helmholtz Centre for Polar and Marine Research,

Telegrafenberg A43, 14473 Potsdam, Germany; e-mail: Paul.Overduin@awi.de

${ }^{5}$ Department of Geography, Memorial University of Newfoundland, St. John's, NL, A1B 3X9, Canada; e-mail: dlforbes@mun.ca

\title{
ICE EFFECT ON COAST AND SEABED IN BAYDARATSKAYA BAY, KARA SEA
}

\begin{abstract}
For the engineering design of underwater pipelines and communication cables in freezing seas, reliable estimates of the frequency and penetration depth of ice-keel scour on the seabed and shoreface are required. Underestimation of ice gouging intensity on the seabed can lead to the infrastructure damage, while overestimation leading to excessive burial depth raises the cost of construction. Here we present results from recent studies of ice gouge morphology in Baydaratskaya Bay, Kara Sea. The direct impact of ice gouging by floes on the seabed and shores is described, generalized and systematized: the depth of the gouges varies from the first centimeters up to $2 \mathrm{~m}$; the most intensive ice gouging is observed near the fast ice rim, due to the maximum impact executed by ice ridges frozen into large floe. We propose a zonation of Baydaratskaya Bay based on the types of ice formation and the intensity of ice impacts on the coasts and sea floor.
\end{abstract}

KEY WORDS: Kara Sea, arctic coastal dynamics, geotechnical safety, sea ice, ice ridges, ice gouging, bottom topography, the intensity of ice influence, zoning.

\section{INTRODUCTION}

Sea ice, as a zonal factor associated with the high latitudes of Arctic seas, plays an important role in the evolution of northern coasts. The ongoing development of oil and gas fields and the construction of relevant engineering facilities in the coastal and shelf areas (including navigation channels, coastal terminals, drilling platforms, submarine pipelines, and artificial islands) require new information on the effects of sea ice on coastal and seabed dynamics [Løset et al., 2006: Lanan et al., 2011]. This is one of the most important factors determining the selection of pipeline landfall sites, shorecrossing design, and required depths of burial.

Until recently, little work has been done in Russia on the interaction between sea ice and the sea floor in coastal regions, whereas abroad, especially in Canada and the USA, there is a long history of research on this topic. American and Canadian researchers have documented the occurrence and processes of bottom scour and related seabed forms associated with pressure ridges and grounded ridges (stamukhi). 
Pioneering studies were undertaken on the Alaska shelf [e.g. Carsola, 1954; Rex, 1955; Reimnitz and Barnes, 1974; Barnes, 1982; Reimnitz and Kempema, 1984; Barnes et al., 1984]. With the help of echo sounders and diving surveys, later augmented by sidescan sonar, ice gouges were found on the sea floor at depths of 0-65 $\mathrm{m}$ (a few deeper), with the highest density in depths of 20-40 m. They were up to $2 \mathrm{~km}$ long, incised as deep as 2,5 m into the sea floor, and were up to $67 \mathrm{~m}$ wide [Barnes et al., 1984]. In the Canadian Beaufort Sea, seminal work by Shearer and Blasco [1975], Lewis [1977], Hnatiuk and Brown [1977] established that ice scour occurred out to about $55 \mathrm{~m}$ depth, was most intense if the depth range of $15-40 \mathrm{~m}$, and that depths of scour penetration were typically $<1 \mathrm{~m}$ but as deep as 7,6 m. Later syntheses of results were provided by Rearic et al. [1990] for the Alaska shelf and Hill et al. [1991] for the Canadian Beaufort Sea. Barrette [2011] provides a recent review of issues related to pipeline protection from ice gouging and Wadhams [2012] provides new estimates of extreme depths and scour frequencies in the Beaufort Sea, recognizing the evidence for a reduction in gouging rates [Blasco et al., 2004], possibly related to a reduction in the frequency of multiyear ice incursion.

Ice gouging is a destructive mechanical impact of ice on the underlying ground surface. This impact on the shore and the floor of the Arctic seas is driven by the ice cover dynamics and mobility, hummocking (ridging), and formation of grounded hummocks (pressure ridges) controlled by hydrometeorological factors and coastal topography [Ogorodov, 2003]. Ice scour and push can extend onto and across the beach as ice pile-up and ice ride-up [Kovacs and Sodhi, 1980; Shapiro et al., 1984; Reimnitz et al., 1990; Forbes and Taylor, 1994], while underwater ice gouging is observed in the coastal zone out to depths of $55 \mathrm{~m}$ or more below the sea level (much deeper in regions of iceberg grounding). In direct observations from submarines, keels of large hummock formations reaching $50 \mathrm{~m}$ depth have been recorded [Lisitsyn, 1994].
In Russia, special studies of the sea ice impacts (first of all, the effect of ice gouging) started significantly later and were carried out in the areas of submarine pipeline construction (Baydaratskaya Bay of the Kara Sea, the Pechora Sea, and the Sakhalin Island shelf [Environmental conditions..., 1997; Vershinin, 2005; Zubakin, 2006].

In 2011, the so-called "Nord-Stream Gas Pipeline" directly connected Russia and Germany through the seabed of the Baltic Sea. In 2013 this pipeline will reach full capacity. To provide gas for this pipeline, in 2005, the "Yamal-Europe" pipeline project [Environmental conditions..., 1997], the lines of which would cross Baydaratskaya Bay, was revived and by August 2007, the construction of the underwater crossing of the main gas pipeline across the Baydaratskaya Bay was underway. This was to connect gas fields of the Yamal Peninsula with the pipeline network in the European part of Russia by the shortest route (Fig.1). The length of the underwater part of the pipeline is approximately $65 \mathrm{~km}$, the maximum bottom depth in the crossing area is $22-23 \mathrm{~m}$. In connection with the renewing of the project, investigations of coastal zone dynamics and sea ice effects continued in 2005 after a 10-year hiatus. In order to assess the impact of the ice on the

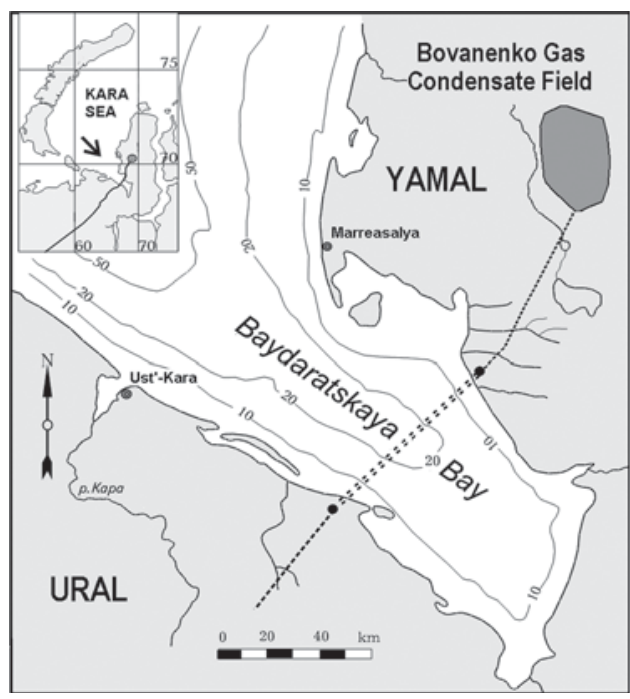

Fig. 1. "Yamal-Europe" gas pipelines crossing Baydaratskaya Bay in the Kara Sea 
sea bottom, a wide range of investigations has been carried out, including field studies as well as mathematical modeling. Some of the results and scientific conclusions of the work in which the authors participated directly are presented in this paper.

\section{ICE CONDITIONS}

The autumn ice formation in Baydaratskaya Bay usually occurs in the absence of residual ice, i.e. in open water. At the beginning of October, as the radiation balance and surface water temperature descend to negative values, the first, usually unstable ice appears. The climatic mean freeze-up date for the formation of stable ice is about 15-20 October. Year-to-year variations in the hydro-meteorological conditions determine the temporal range of freeze-up. In seasons when cold air masses from the Arctic Ocean or the cooled continent prevail, ice formation starts early (the first 10 days of October); in contrast, when warm air from the Atlantic dominates the autumn season, ice formation occurs late (end of November or even into December). In more seaward parts of the bay remote from the shore, freeze-up occurs 1015 days later the ice formation close to shore.

After the ice cover reaches the grey-white stage, the rate of further growth in ice thickness is directly proportional to the intensity of the underlying surface cooling and poorly correlated to the date of stable ice formation. Ice thickness typically increases every 10 days by $8-10 \mathrm{~cm}$ from November to February and then declines to $5-6 \mathrm{~cm}$ per 10 days in March, 2-4 cm in April, and 1-2 cm in May. It is important to note that the mean ice thickness along the shallow Yamal coast is generally greater than along the steep Ural coast. By the end of the cold season, the ice thickness along the Yamal coast reaches 140 $\mathrm{cm}$ on average, i.e. the ice cover in general fits into the category of thick first-year ice. Across the bay along the Ural coast, the annual maximum ice thickness is typically only $120 \mathrm{~cm}$. The ice cover in that area often does not qualify as thick first-year ice and is categorized as medium first-year ice.
The sea ice of Baydaratskaya Bay consists of drift ice and fast ice (Fig. 2a). Close to the open parts of the Yamal and Ural coasts, fast ice forms 20-30 days after the initial freezeup, with a thickness of approximately $30 \mathrm{~cm}$. This young, relatively thin, fast ice is very unstable in the initial stages and therefore it can be easily broken strong wind shear or sea-level rise. However, with the growth of sea ice thickness (up to $0.5 \mathrm{~m}$ ) and the formation of ice hummocks and stamukhas, stabilizing ice conditions, the fast ice resistance increases considerably. Stable fast ice forms near the Yamal coast and in the inner part of the bay only. Next to the Ural coast, fast ice is less stable and in the last several years, cases of its break-away have been observed. In the early part of the season, the fast ice spreads seaward quickly, its outer border reaching the 5-7 $\mathrm{m}$ isobath in November and the 8-10 $\mathrm{m}$ isobath in December. In February-March the seaward border of fast ice corresponds to the isobath of $15 \mathrm{~m}$ at the Yamal coast, where its width is $7-9 \mathrm{~km}$, and to the isobaths of 10-12 m off the Ural coast, where its width is approximately $5-7 \mathrm{~km}$.

Outside the fast ice limits, the central part of Baydaratskaya Bay, in depths of more than 10-15 m, is the area of mobile pack ice. Compared with the immobile fast ice, in the same equal conditions, the thickness of drifting ice is generally less. Along the interface between fast ice and pack ice, as well as on the borders of drifting ice fields, ice hummocks (pressure ridges) form. Ice hummocks freeze into ice fields, building up complex ice formations, which drift together.

Drift ice consists of ice fields of different sizes. Analysis of ice field size for April 2006 based on satellite imagery has shown that most of the ice fields (floes) are less than $2 \mathrm{~km}$ in diameter (Fig. 2a), though several reach sizes of $6-10 \mathrm{~km}$. The maximum vertical dimension of pressure ridges observed in Baydaratskaya Bay, including both the sail and the keel, reaches $30 \mathrm{~m}$, while the length can be up to $300 \mathrm{~m}$. The mass of a $1 \mathrm{~km}$ diameter ice field with ice thickness of $1 \mathrm{~m}$ is approximately $10^{6}$ tons. The mass of the largest pressure 


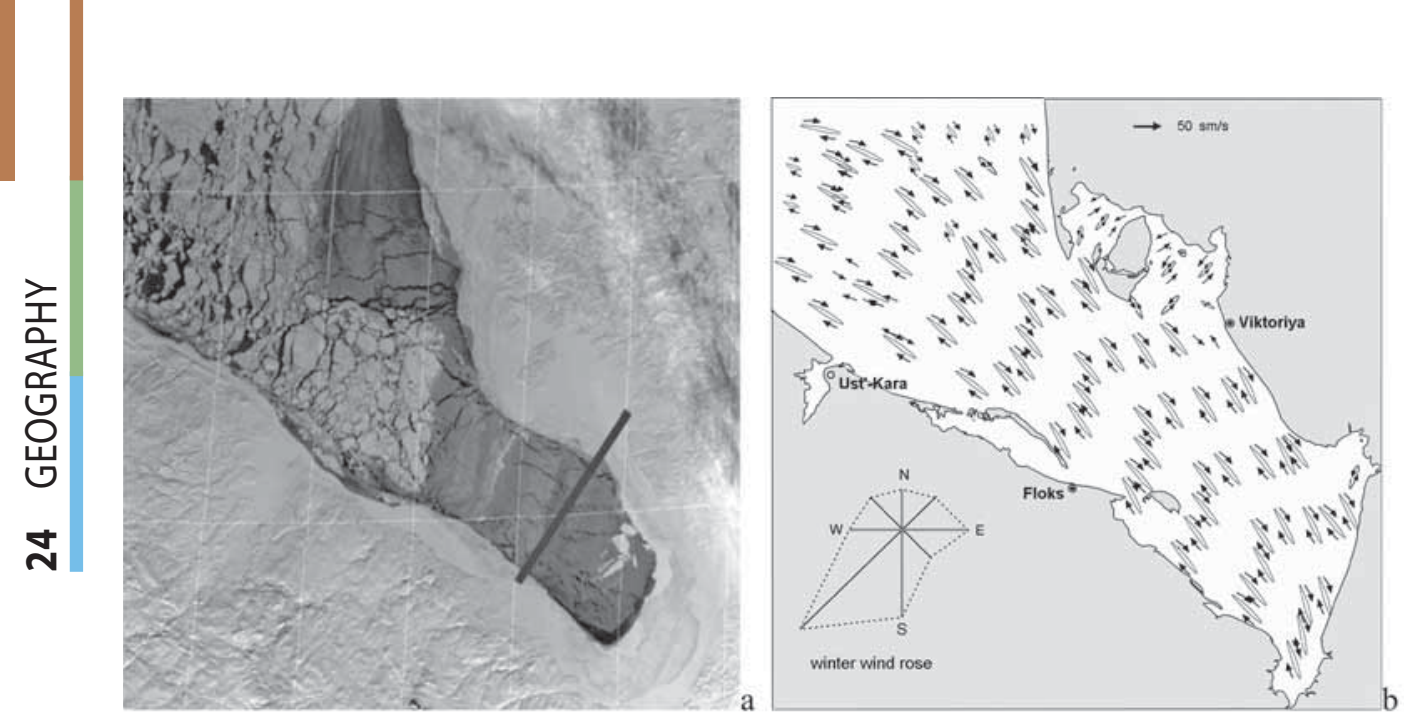

Fig. 2. Baydaratskaya Bay, Kara Sea:

$a$ - ice conditions on 06.03.1999: TERRA satellite image; $b$ - tidal currents [Environmental conditions..., 2007]

ridge $30 \mathrm{~m} \times 30 \mathrm{~m} \times 300 \mathrm{~m}$ is therefore about $2.7 \cdot 10^{5}$ tons, far less than the mass of the $1 \mathrm{~km}$ ice field [Marchenko et al, 2007]. Consequently, the ice scour process in Baydarakskaya Bay is dominated by the mass of ice fields with pressure ridges (ice hummocks and their associated keels) frozen in and incorporated within them, rather than by individual ridges.

The driving forces of ice-field drift are the wind and currents and the shear stress they exert on the upper and lower surfaces of the ice field. Currents measured in the ice-free period are practically reversive and aligned long the axis of the bay. Currents are driven by the semidiurnal tide (Fig. 2b). The maximum speed of the tidal current during the tidal cycle is 0,5, while the measured maximum current speed is 1,0 $\mathrm{m}$ per second. The maximum tidal range (spring tides) is $1.1 \mathrm{~m}$, but including storm surges, the water levels have a range of up to $2 \mathrm{~m}$. During the winter season, southwesterly and southerly winds prevail. In the absence of counteracting currents, these winds create conditions for ice drift from the Ural to the Yamal coast of the bay.

\section{METHODS}

The most commonly used approach to the assessment of sea-ice impacts on the coast and seabed is statistic analysis of data on the distribution and parameters of the ice scour features and the variability of this parameter over time. Acquiring a wide knowledge of the distribution and penetration depth of ice gouges on an extensive area of seabed is possible only with the use of specialized geophysical equipment - side-scan sonar, multibeam sounding, interferometric sidescan, acoustic sub-bottom profilers and GPS/GLONASS positioning systems. Investigations of the bottom ice gouging are conducted from a specialized research vessel equipped with these devices (Fig. 3a). For field surveys of the ice gouging microrelief and determining the morphology and morphometric parameters of ice gouging forms on the sea bottom, we use a complex approach, which allows us to combine the results of several complementary methods. Side-scan sonar and echo-sounding surveys are executed at the same time from the same vessel.

The position of the sounding tracks is determined with high precision using modern GPS and GLONASS receivers, accepting WAAS error corrections. The speed of the vessel during the tracks should not exceed 4 knots. All the information coming from the side-scan sonar, echo sounder, and GPS/GLONASS goes to the computer module and is observed at the monitor in real time. 


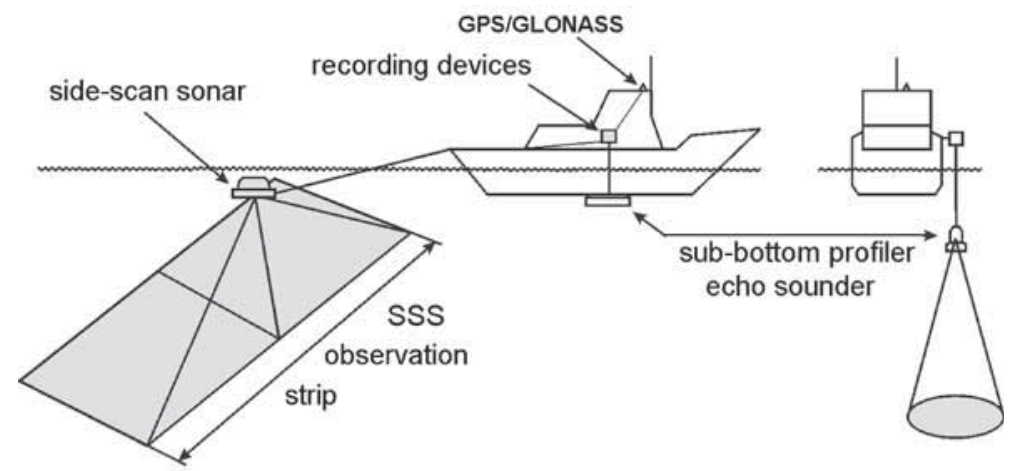

a

\begin{tabular}{|c|c|c|c|}
\hline side scan sonar & GPS/GLONASS & echo sounder & $\begin{array}{c}\text { sub-bottom } \\
\text { profiler }\end{array}$ \\
\hline $\begin{array}{c}\text { orientation, } \\
\text { morphology, } \\
\text { morphometry }\end{array}$ & $\begin{array}{c}\text { location } \\
\text { (coordinates) }\end{array}$ & $\begin{array}{c}\text { morphology, } \\
\text { morphometry }\end{array}$ & $\begin{array}{c}\text { filling of } \\
\text { sediments }\end{array}$ \\
\hline
\end{tabular}

Fig. 3. Geophysical survey technology for mapping seabed features including ice-gouging features:

$$
\begin{gathered}
a \text {-research vessel with geophysical survey devices; } \\
b \text {-selection of geophysical devices to determine the relevant parameters of ice forms }
\end{gathered}
$$

It is registered on the hard drive with the help of the licensed software provided by the sonar equipment suppliers. An echosounding profile shows the morphology and morphometry of the forms (depth, width, etc.), as well as whether they are filled with bottom sediments; the side-scan sonar gives the idea of spatial distribution and orientation of the ice gouging forms (Fig. 3b). Inertial motion units tracking the 3D motion of the survey vessel improve quality by reducing the noise arising from pitch, roll, yaw, or (more commonly) combinations of all three.

As a rule, such investigations are conducted with the aim of assessing ice gouging impacts on the seafloor and oil and gas transportation infrastructure (trenches, pipelines) on the bottom. The spatial resolution of the soundings is determined by proximity to the projected objects and the necessity of repeating previous sounding tracks. To assess the intensity of the ice scour at the present time, it is necessary to conduct repeated soundings and to distinguish forms which appeared between the two measurements. In the context of climate change, identification of "fresh" gouges is especially important in light of the climate warming of the last few years causing changes in the ice regime and displacing the maximum impact zone towards shallower water.

In this study, the position of the pipeline and the number, depth, width, orientation and bottom sediment fill of the ice scour troughs which have appeared between investigations conducted in different years are documented. For this purpose, the tracks of new surveys should coincide with the previous ones, and the same type of equipment should be used. The field stage is only the first step in the complex geophysical survey processing stream. This work enables statistical processing of morphometric data on the ice gouging forms, distribution, and parameters.

Accounting for very recent climate changes, the best time for conducting geophysical surveys in the coastal and shelf zone of the Russian Arctic is from the second half of July to the beginning of August, when the water areas are ice-free and storms are least frequent. 
In areas of shallow water, where ice gouging microforms do not remain stable due to high hydrodynamic activity, preliminary reconnaissance investigations of the fast ice cover are conducted, with the aim of determining the position of stamukhi and hummock ridges, which are fixed with GPS/ GLONASS. Shallow water sounding using side-scan sonar and an echo sounder are performed from smaller vessels immediately after fast ice melting, in order to identify new ice scour features formed by stamukhi before they are obscured by wave and current action.

Diving is a complementary activity which is conducted mostly for the confirmation of geophysical interpretation of the ice gouging forms. Divers acquire underwater photo and video imagery, take samples, and perform experiments for determining the speed of sedimentation in the ice gouging forms.

Besides ice gouging relief sounding on the sea bottom, coastal investigations are performed. As a rule, observations are made directly before the water area becomes icefree. Using GPS/GLONASS and laser total stations, morphological and morphometric parameters of ice formations (ice piles, stamukhi, hummock ridges) and ice microforms created by them (gouges, pits, ridges) are measured.

\section{RESULTS AND DISCUSSION}

The first subdivision of the coastal zone of Baydaratskaya Bay by the types of ice formation and their effect on the sea coasts and floor was by V.A. Sovershaev [Environmental conditions..., 1997], who has made a huge contribution to studies of Arctic coastal dynamics. Detailed investigations performed in recent years under the guidance of the lead author, have made it possible to refine Sovershaev's model regarding the characteristics of ice formation as well as understanding of the mechanisms of ice scour (Fig. 4). Moving offshore down the underwater slope, we can observe the mechanisms and features of the coastal zone of Baydaratskaya Bay and the general types of ice formations and bottom topography changes caused by them.

Sea coasts are affected by ice during the periods of ice formation in autumn and fast-ice destruction and break-up in spring. On shoreline composed of sand-pebble material, the imprint of ice push is clearly defined. Our surveys reveal the widespread occurrence of ridges formed by ice-push (Fig. 5a). In autumn and early winter, young sea ice (20-40 cm thick) can be pushed onshore through wind-driven ice ride-up (unbroken floe) or pile-up (equivalent to pressure-ridge formation). During an icepush event, the solid ice cover trims off the beach sediments and forms ridges of

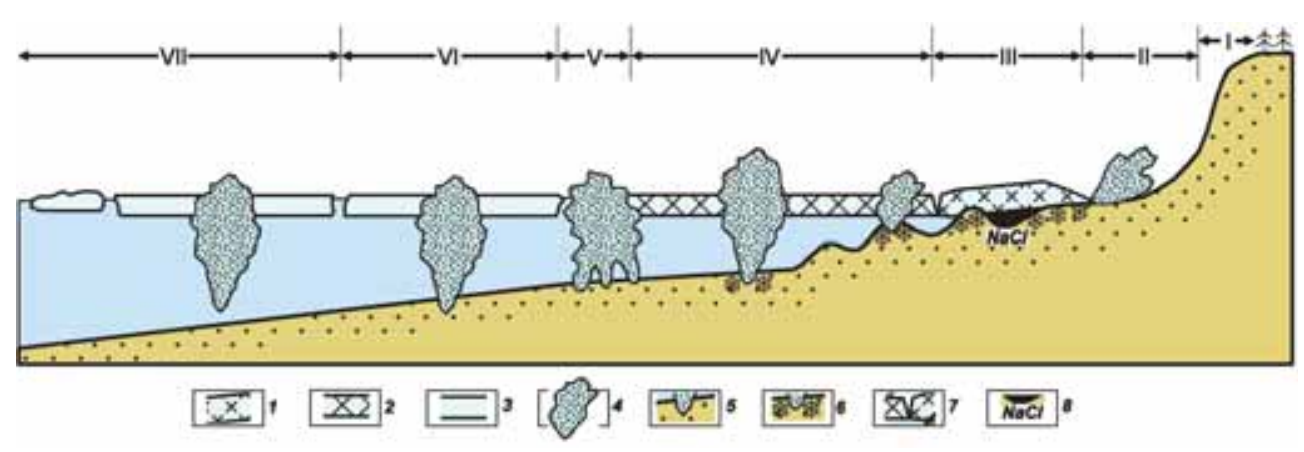

Fig. 4. Subdivision of coastal zone by types of ice formations and their effects on coasts and seabed:

1 - fast ice frozen to the bed; 2 - floating fast ice; 3 -drift ice floes;

4 - hummocks ice formations (ice ridges, grounded hummocks and ice dam), ice piles and overthrusts;

5 - hummock keel penetration into the ground; 6 - seasonally frozen ice forming at contact between ice and bed; 7 - tidal crack; 8 - high-salinity water in longshore troughs, cryopegs 

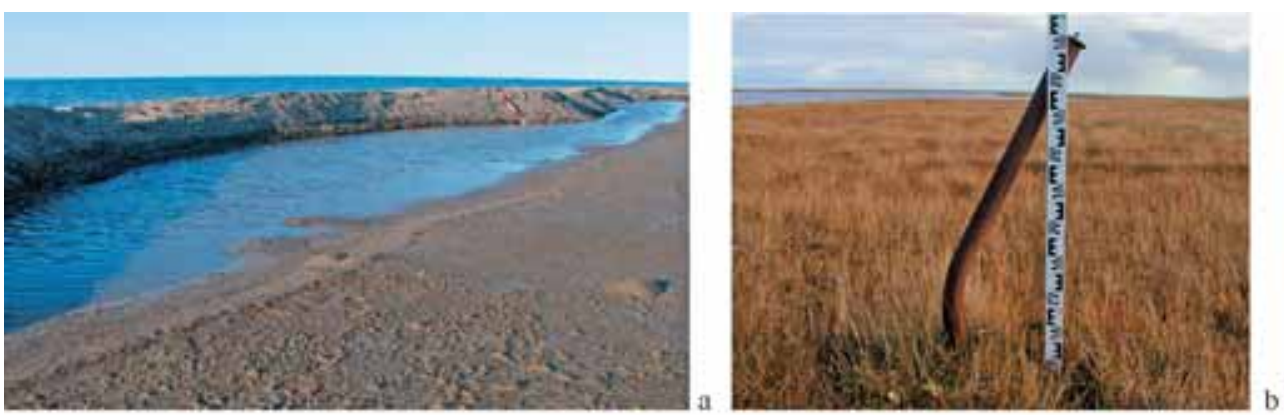

Fig. 5.

a-ice-pushed ridge (photo by N.V.Kopa-Ovdienko),

$b$-coastal dynamics monitoring network bench mark damaged by sea ice overthrust

unsorted material [Barnes, 1982]. In spring the ice also produces small-scale forms, such as furrows, striations, wallow depressions and also various ice-pushed ridges, all of which appear on sandy beaches [Forbes and Taylor, 1994]. The depth of these forms does not usually exceed $0,5-1,0 \mathrm{~m}$, and the length is typically $<50 \mathrm{~m}$. Most ice gouges are oriented transverse to the coastline. These forms, along with most of the ice squeezing forms, are usually preserved until the first considerable storm.

On maritime lowlands that can be flooded during high storm surges, sea ice can be brought inland as far as tens and even hundreds of meters, which causes surface scouring and infrastructure damage. In Baydaratskaya Bay, geodetic benchmarks give evidence of these processes. Most of the benchmarks lower than 2,5 $\mathrm{m}$ a.s.l. are bent near the base (Fig. 5b).

Thethermal effects ofseaicearealso important where the ice becomes bottomfast, allowing the formation of seasonally frozen ground and the preservation of relict permafrost beneath the seabed. These phenomena are widely recognized in the shallow areas of Baydaratskaya Bay [Sovershaev et al., 1988]. The presence of bottomfast ice in the nearshore and in open shallow areas induces the freezing of bottom sediment and the development of new permafrost areas. The development of bottomfast ice is preceded by the freeze-up of beaches and tide flats and the formation of an ice protective cover. In autumn, developing fast ice freezes to bottom sediments, starting just from the water edge and going on until the sea depth becomes equal to or greater than the ice thickness. This process results in the formation of subaqueous frozen grounds in the areas of freezing. These grounds often alternate with unfrozen grounds cooled below $0^{\circ} \mathrm{C}$ to $-2^{\circ} \mathrm{C}$. The permafrost underlying the sea floor gradually acquires specific subaqueous features, which are expressed through increased temperature, a higher proportion of unfrozen water, and increased salinity of this water. The nearshore profile reveals a "cap" from frozen-ground forms in the landfast ice contact zone and protruding into the sea (Fig. 6).

The chemical effect of sea ice on sea floor can be seen in near-coastal shallows and lagoons in the form of salt depletion in the fast ice during its formation. By the end of winter, when the ice reaches its maximum thickness, these areas become almost completely isolated from the sea and acquire their own salt and temperature regimes different from those in the open sea [cf. Grasby et al., 2013]. The salinity of water in these closed areas exceeds average values; therefore, the water temperature can fall below the freezing point of sea water, leading to the formation of the so-called cryopeg. Similar conditions favoring the cryopeg formation occur in the longshore troughs, when the thickening ice reaches 


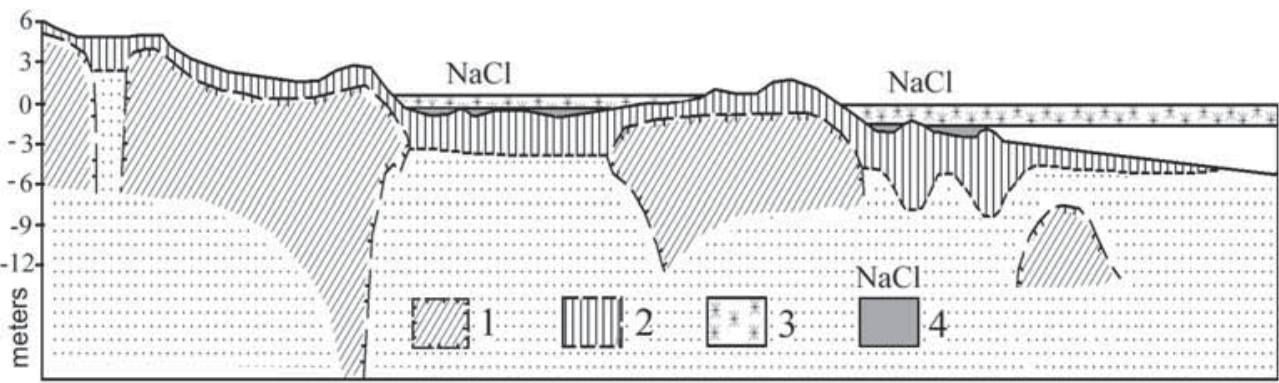

Fig. 6. Geocryological section of the Yamal coast of Baydaratskaya Bay, Kara Sea:

1 - permafrost, 2 - seasonally frozen layer, 3 - sea ice, 4 - cryopegs

the sea floor and freezes to longshore bars [Grigoriev, 1987]. In this case, the longshore troughs also become isolated from the sea. They get filled with high-salinity water which protects bottom ground from freezing.

The mechanical action of the ice on the sea bottom lasts from the onset of ice formation until the sea is completely free of ice. After young ice freezes to the seafloor in the nearshore zone, this new strip of ice serves as a protective buffer. The ridges of hummocks closest to the coast develop above submarine bars [cf. Forbes et al., 2002]. Because of a decreased sea depth above these bars, they become the focus of ridging and, thus the number of hummock ridges commonly corresponds to the number of submarine bars. Due to the onshore pushing impact of sea ice, ice gouges in this zone are mostly oriented normal to the coastline. The effect of the coastal hummock ridges and barriers on beaches and in shallow areas (down to a depth of 7-10 m) can be traced only immediately after fast ice is destroyed. The life expectancy of ice-gouged forms developed on sand beaches and shallow areas is very short, until the first summer storm. These forms, the depth of which is mainly $<0.5 \mathrm{~m}$, commonly disappear with the first strong waves in summer and autumn.

Further out in the bay, the pattern of hummocky pressure ridges is irregular and controlled by hydrodynamic factors, particularly the location of the fast ice edge during storms. Storm winds can destroy the fast ice edge and form a new ridge of hummocks or single grounded hummocks (Fig. 7a). The pattern of ice plowing in this case is either chaotic or parallel to the coastline. This is due to the prevailing along-shore drift of hummock formations. After the final onset of the fast ice the stamukhi remain non-mobile, often frozen down to the bottom. After their melting and wave destruction, small (up to $1 \mathrm{~m}$ deep) holes and shallow, relatively short ice gouges remain (Fig. 7b, c). Ice gouges in this area are oriented mostly either chaotically or normally to the coastline, which is enhanced by the pressure of ice from the seaward side. Due to high hydrodynamic activity here, the gouges are quickly smoothed, and the gouge density in shallow areas is lower than in the zone of the fast ice edge.

The fast ice edge (within Baydaratskaya Bay near the 10-15 $\mathrm{m}$ isobaths) is the zone where the ice impact on the sea floor is the strongest. Here, pressure ridges reaching the floor ("ice dam") develop throughout the winter (Fig. 8a). In this case, ice gouges form a so-called "comb", usually oriented normal to the coastline due to the pressure of ice from the open sea. In 2007, during sonar tracking from the research vessel Ivan Petrov, such a "comb" was observed with dimensions of approximately $70 \mathrm{~m}$ wide and $400 \mathrm{~m}$ long; it consisted of a system of parallel ice gouges up to 1,5 $\mathrm{m}$ deep (Fig. 8b). Ice gouges are well preserved at this depth. They can be partly smoothed during extreme storms only. At depths of 14-16 m (within Baydaratskaya Bay), the 
occurrence and density of ice gouges turns out to be lower than at greater depths, though ice gouging is the most intense (most of the mobile systems of hummocks and grounded hummocks are formed here). The above situation is due to more active hydrodynamics at shallow depths, where the wave effect still influences the bottom and the velocities of tidal currents are higher. Due to this, the gouges at depth can exist over several years - first decade years here (as distinct from their short existence in
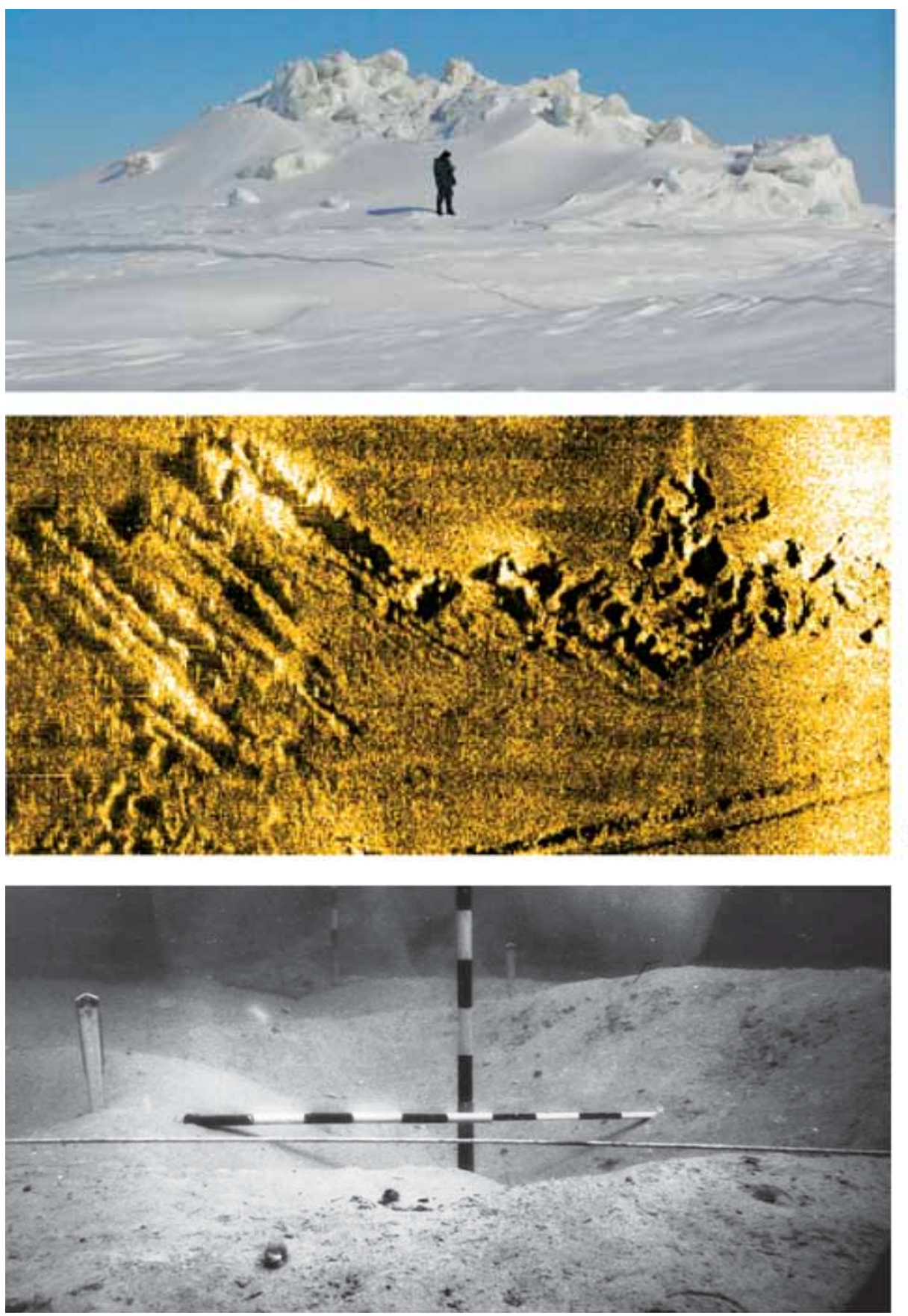


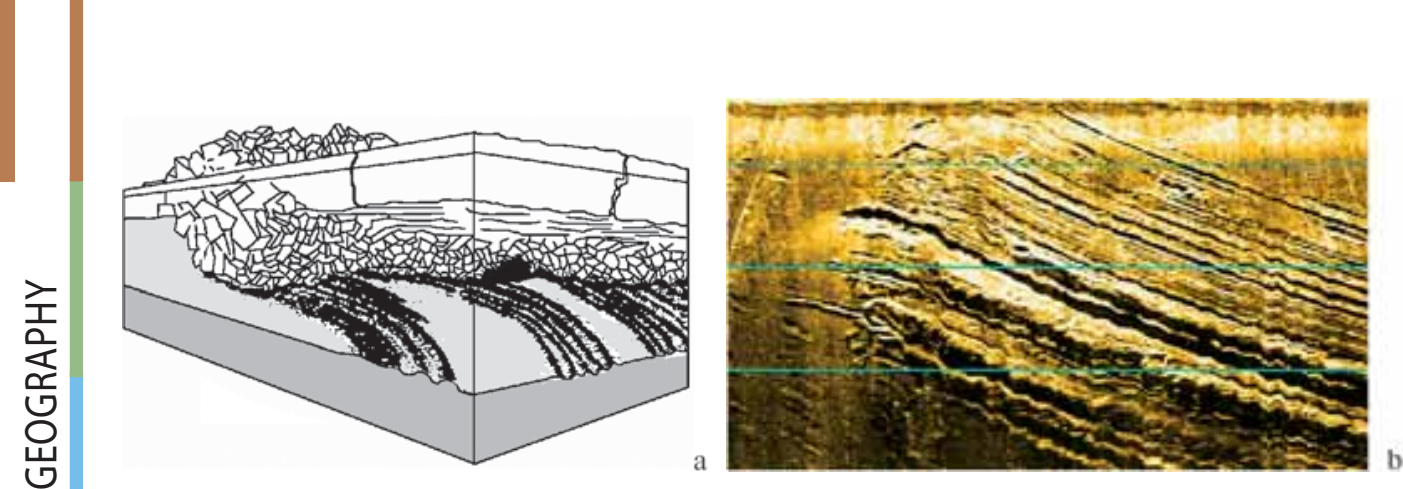

요

Fig. 8. Ice dam and its effect on the seabed
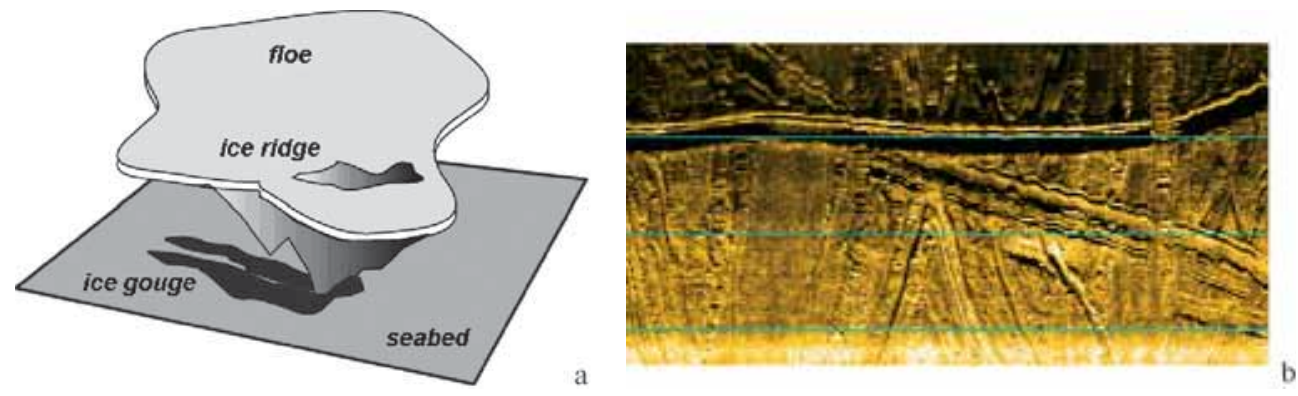

Fig. 9. Ice gouging by hummock frozen into the floe

shallow areas), gradually smoothing over and vanishing.

The most intensive and deep ice gouges occur in the area of drift ice at the range of depths from 16 to $19 \mathrm{~m}$, next to the Yamal coast fast-ice rim, where ice hummocks is going on during the whole cold season and along which ice fields and hummocks, reaching the bottom frozen into them drift (Fig. 9a). Given the fact that the mass of the whole ice formation (floe and hummock) participates in the ice gouging, the deepest (up to $2 \mathrm{~m}$ ), the widest (up to $50 \mathrm{~m}$ ) and the longest (up to several $\mathrm{km}$ ) ice gouges have been observed in this area (Fig. 9b). They are oriented conformably with tidal currents directions - lengthwise the Baydaratskaya Bay [Marchenko et al., 2007]. Due to the low hydrodynamic activity at these depths, unaffected by wave action, the rates of sedimentation are very low. As a result, ice gouges are well preserved on the sea bottom and are mostly superimposed. Sometimes they cover up to $100 \%$ of the sea bottom [Ogorodov, 2003]. Deeper than 19

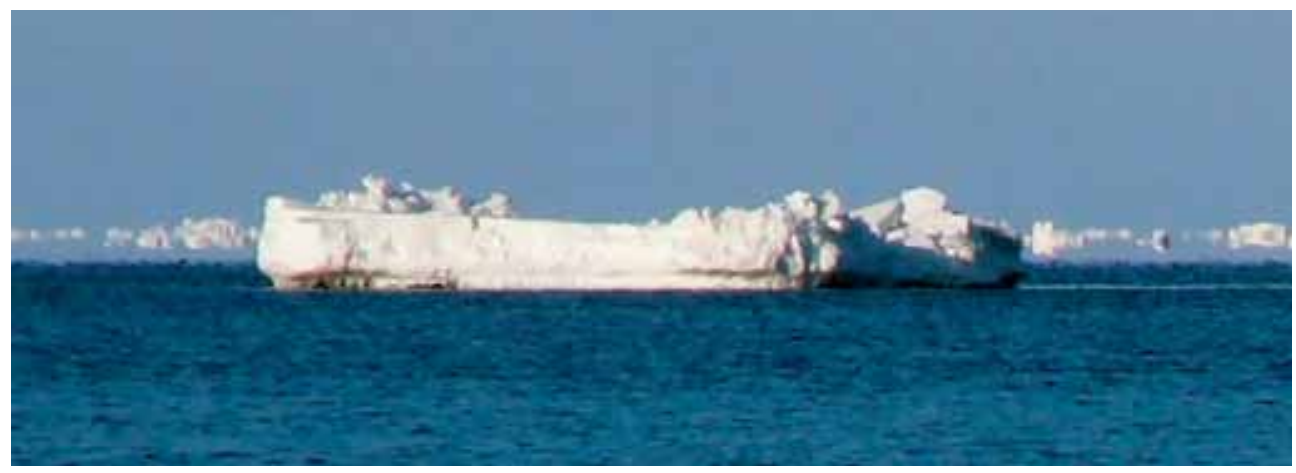

Fig. 10. Iceberg at the pipeline route "Yamal-Europe", May 2007 (photo by A.M. Kamalov) 

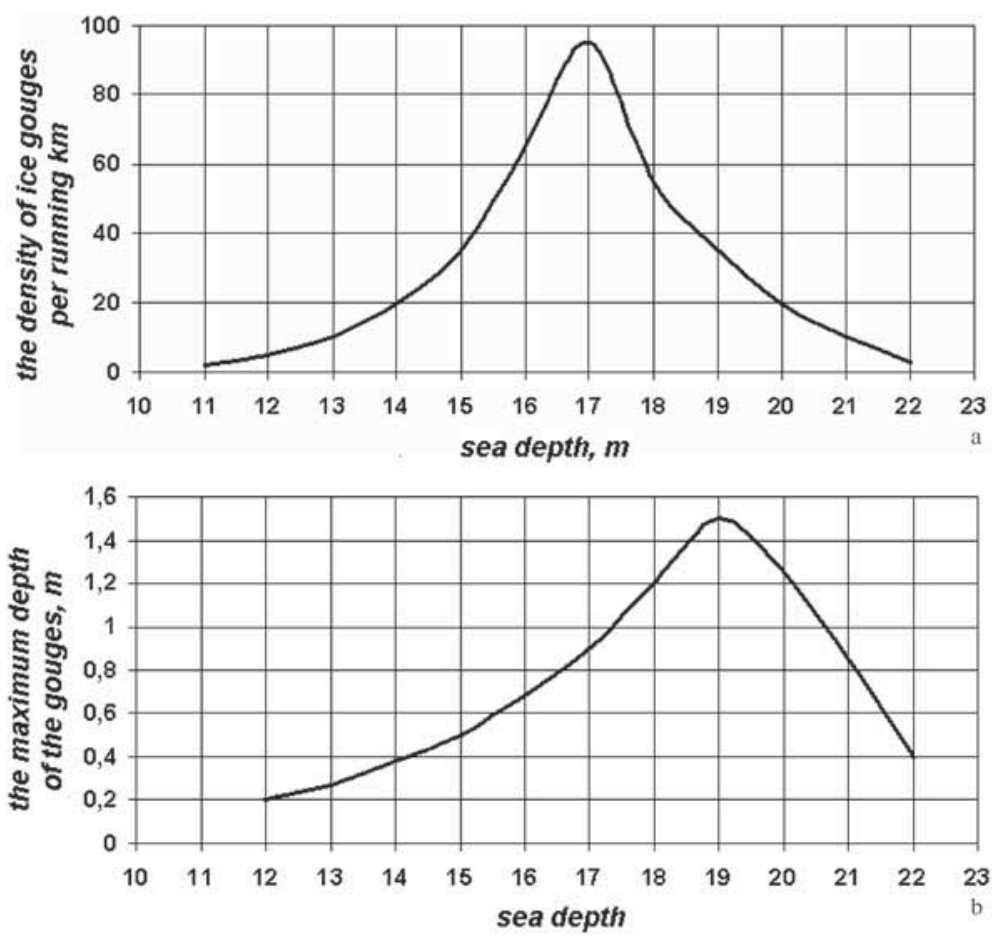

Fig. 11. The distribution of the density (a) and depth $(b)$ of the ice gouges with sea depth

m, ice gouges occur rather frequently. However, ice formations rarely occur at these depths. This situation is caused by a low hydrodynamic activity and low sedimentation rates. Under such conditions, the gouges, especially large ones, can exist on the bottom surface for decades. Thus, a low intensity of ice gouging is compensated by the long life of gouge forms. This "accumulation" effect gives a false impression of a high intensity of ice gouging here.

At depths exceeding the maximum possible hummock thickness, 23-26 $\mathrm{m}$ in this area, bottom ice gouging stops. Ice gouges are rarely observed here. The hypothesis is that ice gouges at these depths are left by icebergs. Icebergs have been documented in Baydaratskaya Bay documented very rarely, including in 1932 and 2007 (Fig. 10). It is possible that the appearance of icebergs is connected to warm periods and occurs during the time of minimum ice cover of the water area.

Investigations on the Baydaratskaya Bay, Kara Sea show that the depth of ice gouges and the density of ice gouging forms reach their highest values at depths of 17-19 m (Fig. 11a, b). However, this does not denote that the intensity of ice gouging is lower in shallow depths with rarer occurrence and smaller depth of ice gouges. The main method of indirect estimation of ice gouging intensity is the estimation of ice gouges' density and depth. Meanwhile, the lifetime of such forms can essentially vary according to sea depth, type of the sediments and the duration of dynamically active period, so the question about sea ice gouging intensity of the coasts and bottom is directly connected with the problem of ice gouging forms' preservation [Ogorodov, 2011].

The depth of ice gouging forms depends not only on sea depth, ice thickness and intensity of sheer stress, but also on the composition and state of bottom deposits. The shape of ice gouging forms probably depends on plasticity, mobility and granulometric composition of the sediments as well. However, no simple correspondence was found between field data on the 
occurrence and density of gouges and the type of sediments, except in a very few cases. Observations shows that ice gouges, especially large ones, have considerable lengths, sometimes up to several kilometers, i.e. hummocks can constantly gouge the bottom for a long time due to their large kinetic energy. Therefore hummock can gouge bottom sections with rather different characteristics of the sediments.

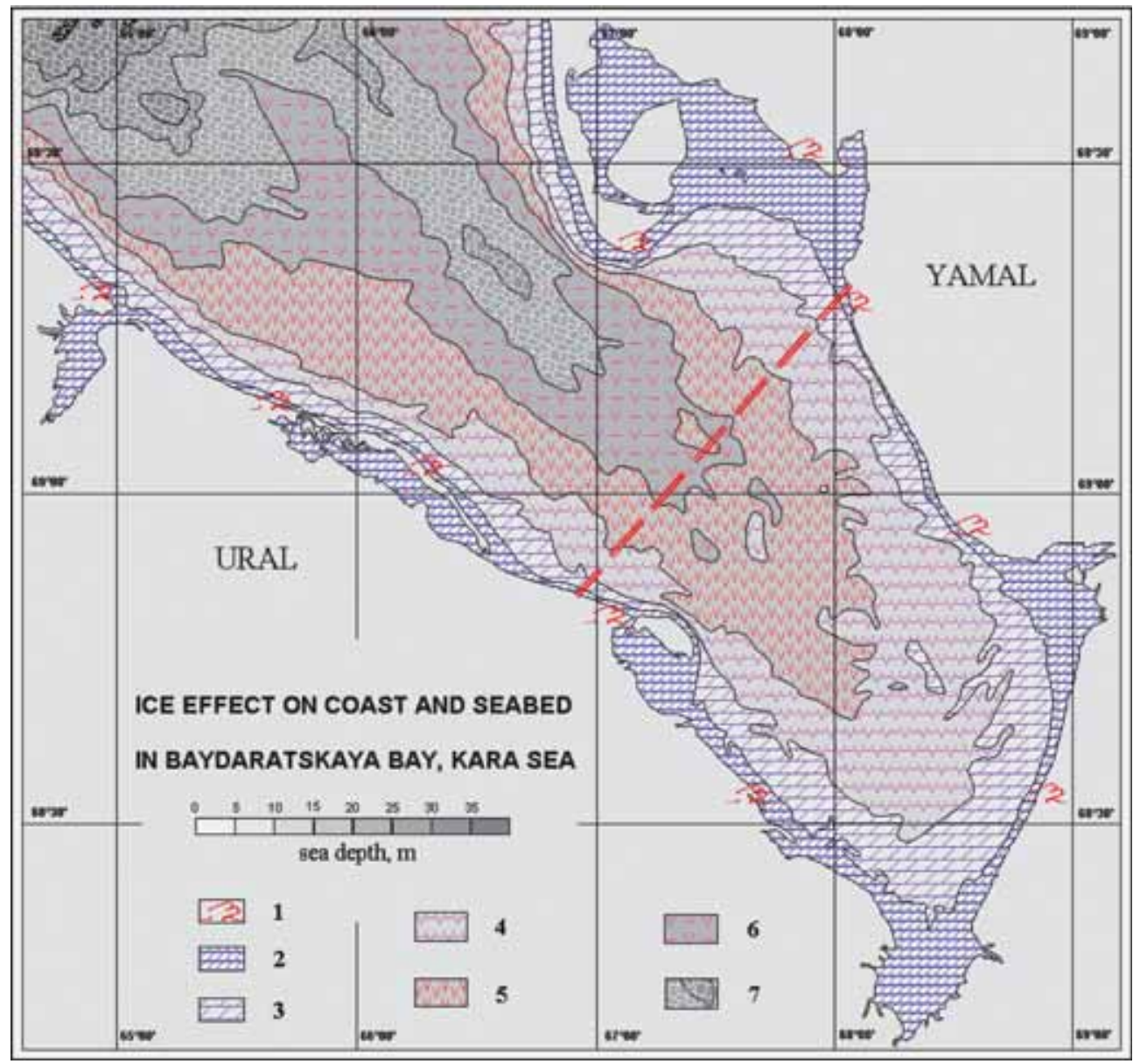

Fig. 12. Map of the arias with different intensity of the sea ice impact on the coasts and bottom of Baydaratskaya Bay, Kara Sea. Legend:

1 - sea ice overthrust on low coasts, beaches and foreshores area; 2 - area of development of stable fast ice "on the bottom" with sites where the ices freezes to the ground near the water edge, on underwater bars and shallow gulfs. Sea ice formations: hummocks ridges and stamukhi are situated on underwater coastal bars. The ice gouging is limited by the stableness and immobility of the fast ice; 3 - area of unstable "floating" fast ice. Ice hummocks ridges developed along the coast, "ice barriers" and separate stamukhi correspond to the periods of contraction due to pressure at the forming fast ice rim, reflecting the stages of its prorogation. Ice gouging intensity is medium; 4-area of ice hummocks at the fast ice rim. High intensity of bottom ice gouging as a result of pressure-forced movements of the ice cover towards the land and the action of ice hummocks drifting along the fast ice rim; 5-drifting ice area. The most intensive ice gouging is caused by the keels of the ice hummocks, frozen into the ice floe drifting with the tidal currents; 6 - drifting ice area. Formation of big ice gouges by the keels of heavy low-sitting hummocky formations frozen into the ice fields and remnants of icebergs drifting with tidal currents; 7-area of drifting ice out of the zone of ice gouging impact. Keels of the ice formations mostly don't reach the bottom. The probability of ice gouging is low 
Based on an integrated analysis of ice conditions, bathymetry and results of statistical processing of the ice gouges' frequency obtained as a result of expeditions in 2005-2012, a map-scheme "Sea ice impact on the coasts and bottom of the Baydaratskaya Bay, Kara Sea" has been developed (Fig. 12). Several zones, in which the mechanisms and the intensity of the ice impacts vary considerably, have been selected within the bay. The sea bottom experiences the strongest impacts at 15$20 \mathrm{~m}$ depth - the area of ice floes with hummock formations frozen into them, which drift with the help of tidal currents along the fast ice rim. Most parts of the underwater pipeline crossing "Yamal-Europe" are situated in this zone. Therefore it will be necessary to consider the ice factor while laying the $3^{\text {rd }}$ and the $4^{\text {th }}$ pipeline runs as well as to conduct constant monitoring of the already laid pipeline runs to establish the frequency and depth of bottom disturbance over them by ice formations. The buried pipeline and the covered trench where the pipelines have already been built are literally a "blank sheet of paper" and an ideal polygon for sea bottom ice scour monitoring.

\section{CONCLUSIONS}

Based on a detailed analysis of the sea ice impacts on the coasts and bottom of Baydaratskaya Bay, Kara Sea, and on the zoning of the pipeline crossing area, the following conclusions can be drawn:

- Coasts between 2 m above sea level and $26 \mathrm{~m}$ below sea level experience the influence of sea ice scour or gouging;

- For Baydaratskaya Bay ice gouges can be up to $2 \mathrm{~m}$ deep, $50 \mathrm{~m}$ wide, and several kilometers long;

- At the depths of more than $14 \mathrm{~m}$ for the Ural section and more than $12 \mathrm{~m}$ for the Yamal section, ice gouges are the most frequent bottom features, which infer that at these depths gouging is the main controlling factor of the bottom relief formation. For shallower depths, ice gouging relief is re-worked by wave processes;

- $80 \%$ of the observed gouges have a north-west - south-east orientation (or close to it), consistent with the general shape and alignment of Baydaratskaya Bay and the pattern of tidal currents;

- With increasing depth, the "life span" of the ice gouges also grows, such that they can be preserved for tens to hundreds of years; and for some of the areas 100\% of the seabed is covered by these gouging artefacts;

- Taking into consideration the varying hydrodynamic activity and different "age" of the ice gouging forms, the intensity of the ice impacts can not be determined solely from the density or frequency of the ice gouges;

- The highest ice gouging intensity occurs along the winter rim of the landfast ice off the Yamal coast and in the adjacent drift-ice area;

- The underwater pipeline "YamalEurope" crossing is situated in the most dangerous area; this should be considered when projecting the burial depths for the pipes. Constant monitoring of the ice impacts on the bottom is also necessary.

\section{ACKNOWLEDGEMENTS}

This work was partially supported by Federal Target Program "Scientific and academic teaching staff of the innovative Russia" (\#8508), "Coastal Zone of Yamal Peninsula: Environmental Conditions and Permafrost Dynamics" Total E\&P Recherche Developpement, "Helmholtz RussianGerman Joint Research Group, HGF-100" and "Sustainable Arctic Marine and Coastal Technology" (SAMCOT) projects. Participation by Donald Forbes is supported by ArcticNet and the Canadian Networks of Centers of Excellence. 


\section{REFERENCES}

1. Barnes, P.W. (1982) Marine ice-pushed boulder ridge, Beaufort Sea, Alaska // Arctic, v. 35, N 2, p. 312-316.

2. Barnes, P.W., Rearic, D.M. and Reimnitz, E. (1984) Ice gouging characteristics and processes. In: The Alaskan Beaufort Sea: Ecosystems and Environments (eds. P.W. Barnes, D.M. Schell, E. Reimnitz). Academic Press, Orlando, p. 185-212.

3. Barrette, P. (2011) Offshore pipeline protection against seabed gouging by ice: an overview // Cold Regions Science and Technology, v. 69, N 1, p. 3-20.

4. Blasco, S.M., Shearer, J.M., Campbell, P., Wright, B. and Melling, H. (2004) Reduction in sea ice scour impact rates on the seabed 1979-2003, Canadian Beaufort Sea. American Geophysical Union, Spring Meeting, abstract C43A-10.

5. Carsola, A.J. (1954) Extent of glaciation on the continental shelf in the Beaufort Sea // Amer. J. Sci. v. 252, N 6, p. 366-371.

6. Environmental conditions of the Baydaratskaya Bay. Main results of investigations for construction of submarine passage) (1997). Moscow, GEOS, 432 p. (in Russian).

7. Forbes, D.L. and Taylor, R.B. (1994) Ice in the shore zone and the geomorphology of cold coasts // Progress in Physical Geography, v. 18, N 1, p. 59-89.

8. Forbes, D.L., Manson, G.K., Chagnon, R., Solomon, S.M., van der Sanden, J.J. and Lynds, T.L. (2002) Nearshore ice and climate change in the southern Gulf of St. Lawrence // Ice in the Environment: Proceedings, 16th International Symposium on Ice. International Association of Hydraulic Engineering and Research, Dunedin, New Zealand, p. 344-351.

9. Grasby, S.E., Smith, I.R., Bell, T. and Forbes, D.L. (2013) Cryogenic brine and mirabilite precipitation formed by marine transgression of high latitude coastal lake basins - Sachs Harbour, western Canadian Arctic // Geochimica et Cosmochimica Acta, v. 110, p. 13-28.

10. Grigoriev, N.F. (1987) Permafrost at the coastal part of Western Yamal // Proceedings of the Institute of Permafrost of the USSR. Yakutsk. 112 p. (in Russian).

11. Hill, P.R., Blasco, S.M., Harper, J.R. and Fissel, D.B. (1991) Sedimentation on the Canadian Beaufort Shelf // Continental Shelf Research, v. 11, N 8-10, p. 821-842.

12. Hnatiuk, J. and Brown, K. (1977) Sea bottom scouring in the Canadian Beaufort Sea // Proceedings $9^{\text {th }}$ Annual Offshoe Technology Conference, Houston, v. 3, p. 519-527.

13. Kovacs, A. and Sodhi, D.S. (1980) Shore ice pile-up and ride-up: field observations, models, theoretical analyses // Cold Regions Science and Technology, v. 2, p. 209-288.

14. Lanan, G.A., Cowin, T.G. and Johnston, D.K. (2011) Alaskan Beaufort Sea pipeline design, installation and operation. // Proceedings of OTC Arctic Techology Conference, Houston, Texas, February 7-9. Offshore Technology Conference, 9 p.

15. Lewis, C.F.M. (1977) Estimation of the frequency and magnitude of drift-ice groundings from the ice scour tracks in the Canadian Beaufort Sea // Proceedings, $4^{\text {th }}$ International Conference on Port and Ocean Engineering under Arctic Conditions, St. John's NL, v. 1, p. 568-579.

16. Lisitzyn, A.P. (1994). Sea-ice sedimentation in the World Ocean. Moscow, Nauka, 448 p. (in Russian).

17. Løset, S; Shkhinek, K.N; Gudmestad, O.T; Høyland, K.V. (2006) Actions from Ice on Arctic Offshore and Coastal Structures, St. Petersburg: LAN. ISBN 5-8114-0703-3. 271 p. 
18. Marchenko, A.V., Ogorodov, S.A., Shestov, A.V. and Tsvetsinsky, A.S. (2007) Ice gouging in Baydaratskaya bay of the Kara Sea: field studies and numerical simulations // Proceeding of $19^{\text {th }}$ International Conference on Port and Ocean Engineering Under Arctic Conditions "Recent Development of Offshore Engineering in Cold Regions", POAC-07, Dalian, China, June 27-30. Edited by Qianjin Yue Shunying Ji. Dalian University of Technology Press, Dalian, P. 747-759.

19. Ogorodov, S.A. The Role of Sea Ice in Coastal Dynamics. - Moscow University Press, 2011, 173 p. ISBN 978-5211-06275-7. (in Russian).

20. Ogorodov, S.A. (2003) The Role of Sea Ice in the Coastal Zone Dynamics of the Arctic Seas // Water Resources, v. 30, N 5, p. 509-518.

21. Rearic, D.M., Barnes, P.W. and Reimnitz, E. (1990) Bulldozing and resuspension of shallowshelf sediment by ice keels: implications for particle sediment transport trajectories // Marine Geology, v. 91, p. 133-147.

22. Reimnitz, E., Barnes, P.W. (1974) Sea ice as a geologic agent on the Beaufort Sea shelf of Alaska // The Coast and Shelf of the Beaufort Sea (eds. J.C. Reed and J.E. Sater). Arctic Institute of North America, Arlington. p. 301-353.

23. Reimnitz, E. and Kempema, E.W. (1984) Pack ice interaction with Stamukhi Shoal, Beaufort Sea, Alaska. In: Alaskan Beaufort Sea: Ecosystems and Environments (eds. P.W. Barnes, D.M. Schell, E. Reimnitz). Academic Press, Orlando, p. 159-183.

24. Reimnitz, E., Barnes, P.W. and Harper, J.R. (1990) A review of beach nourishment from ice transport of shoreface materials, Beaufort Sea, Alaska // Journal of Coastal Research, v. 6, p. 439-470.

25. Rex, R.W. (1955) Microrelief produced by sea ice grounding in the Chukchi Sea near Barrow, Alaska // Arctic, v. 8, N 3, p. 177-186.

26. Shapiro, L.H., Metzner, R.C., Hanson, A. and Johnson, J.B. (1984) Fast ice sheet deformation during ice-push and shore ice ride-up. In: Alaskan Beaufort Sea: Ecosystems and Environments (eds. P.W. Barnes, D.M. Schell, E. Reimnitz). Academic Press, Orlando, p. 137-157.

27. Shearer, J.M. and Blasco, S.M. (1975) Further observations of the scouring phenomenon in the Beaufort Sea. Geological Survey of Canada, Paper 75-1.

28. Sovershaev, V.A., Voskresenskiy, K.S., Kamalov, A.M., Romanenko F.A. (1998) The development of coastal accumulative forms in permafrost // Dynamics of the Arctic coasts of Russia. Ed. V.I.Solomatin and V.A.Sovershaev. Moscow. MSU. P. 80-92. (in Russian).

29. Vershinin, S.A., Truskov, P.A., Kuzmichev, K.V. (2005) Ice effect on the constructions at Sakhalin shelf. Moscow: "Giprostroymost Institute", 208 c. (in Russian).

30. Wadhams, P. (2012) New predictions of extreme keel depths and scour frequencies for the Beaufort Sea using ice thickness statistics // Cold Regions Science and Technology, v. 76-77, p. 77-82.

31. Zubakin, G.K. (ed.) (2006) Ice formations in the Western Arctic seas. St. Petersburg. AARI. 272 p. (in Russian). 


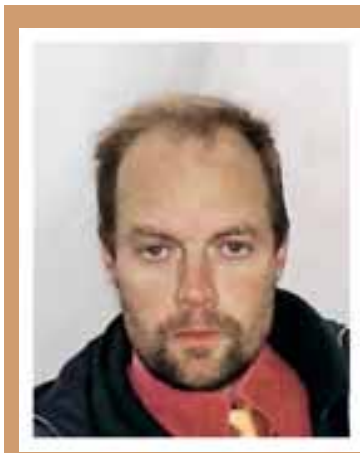

Pier P. Overduin studied at Wilfrid Laurier and York Universities in Canada, and completed a Ph.D. at the University of Alaska Fairbanks in 2005. Since 2006 he is a Senior Scientist in the Periglacial Research Department at the Alfred Wegener Institute for Polar and Marine Research in Potsdam, Germany. His research focuses on submarine permafrost and coastal dynamics in the Arctic. Main publications: Short and long-term thermo-erosion of ice-rich permafrost coasts in the Laptev Sea region (2013, with co-authors); Geoelectric observations of the degradation of near-shore submarine permafrost at Barrow (Alaskan Beaufort Sea) (2012, with co-authors); Evolution and degradation of coastal and offshore permafrost in the Laptev and East Siberian Seas during the last climatic cycle (2007, with co-authors).

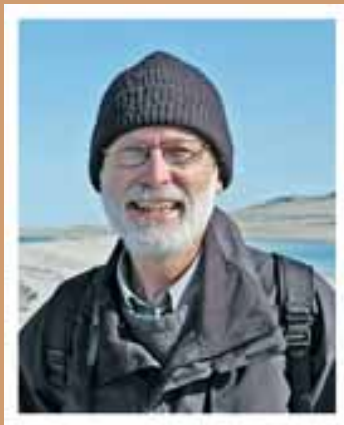

Donald L. Forbes obtained his Ph.D. at the University of British Columbia in 1981. In 2012 he retired from the Geological Survey of Canada after 31 years of research on coastal dynamics, paraglacial coasts, and climate-change impacts and adaptation. $\mathrm{He}$ is an Adjunct Professor at Memorial University of Newfoundland and co-leads the coastal project in ArcticNet. Main publications: Polar coasts (2012, with J.D. Hansom); Glaciated coasts (2012); State of the Arctic Coast 2010: Scientific Review and Outlook (2011, editor); Ice in the shore zone and the geomorphology of cold coasts (1994, with R.B. Taylor). 